\title{
Correlation and path coefficient studies of Cocoyam (Xanthosoma sagittifolium L.)
}

\author{
K. K. Paul ${ }^{1 *}$ and M. A. Bari ${ }^{2}$ \\ ${ }^{I}$ Govt. shahid Bulbul College,Pabna-6600,Bangladesh. \\ ${ }^{2}$ Institute of Biological Sciences, Rajshahi University, Rajshahi-6205, Bangladesh.
}

\begin{abstract}
Plant height, leaf length, leaf breadth, leaf number, leaf area index, corm length, corm breadth, corm weight, sucker number exhibited positive correlation with yield per plant in both genotypic and phenotypic level in cocoyam (Xanthosoma sagittifolium). Path coefficient analysis revealed that leaf length, leaf number, corm length exhibited direct influences to yield per plant. In genotypic level yield per plant showed the highest positive direct effect with corm length followed by cormel breadth, sucker number.
\end{abstract}

Key words: Cocoyam; Correlation coefficients; Path coefficient; Xanthosoma sagittifolium

\section{Introduction}

Cocoyam, Xanthosoma sagittifoium L. Schott (locally called maulavi $k a c h u$ ) is a herbaceous perennial absolutely an under utilized root crop of Araceae family. The edible species of Xanthosoma originated from tropical America but are now widely grown as subsistence food crop in Africa, Asia and Polynesia. The crop is mainly cultivated by small scale farmers (Onwueme and Charles,1994) in Asia, Africa, and Latin America (Coursey,1983; Wilson1984) as a source of carbohydrates and for cash income (Tambong et al., 1997;1999). In Nicaragua, cocoyam is the third most consumed root and tuber crops, after potato, cassava and the second regarding production and use of arable land after cassava (Anomymous, 2005). It is the most important export product of all root and tuber crops grown in Nicaragua (Anomymous, 2005) with 5120 t exported in 2004, mainly to Puerto Rico, the United States of America and Costa Rica. In Bangladesh there are wide range of varieties of aroids some are edible and some are very much wild as distinct by their acridity. Farmers used to cultivate only edible cocoyam and on the basis of cultivation practices edible cocoyam were selected from different localities of Bangladesh.

The world's rapid population growth is demanding increased production and greater diversification of crops. In Bangladesh very little research study has been carried out on this aroid.. Tuber yield is a complex character and governed by the number of component characters. But a breeder is always concerned with the selection of superior genotypes where performance is dependent on the phenotypic expression. Therefore, the knowledge of association of component characters with yield is of great importance to plant breeders as it helps in their selection with more precision and accuracy. Genotypic correlation is the inherit association between two variables and is the main concern of the plant breeder. Estima- tion of genetic association along with phenotypic correlation not only displays a clear picture of the extent of inherent association but also indicates how much of this phenotypically expressed correlation is influenced by the environment. Path coefficient analysis on the other hand determines the direct and indirect contribution of the characters on yield (Wright, 1921). Path coefficient analysis further permits the partitioning of the correlation coefficients into components of direct and indirect factor of association and provides an effective tool in finding out the direct and indirect contribution of different contributing characters towards yield. Therefore knowledge of correlation and path analysis is useful in formulation of effective selection strategy in breeding program. Thus the present investigation was designed to estimate the genotypic and phenotypic correlation and direct and indirect effect among different characters for identification of best genotypes from cultivars of cocoyam towards tuber yield.

\section{Materials and methods}

335 accessions of cocoyam (Xanthosoma sagittifoium) were collected from aroid growing districts namely Rajshahi, Satkhira, Jessore, Bogra, Joypurhat, Munshiganj, Dhaka, Mymensingh and Barisal in Bangladesh. Collected propagules are maintained at the experimental farm of the Institute of Biological sciences at University of Rajshahi,Rajshahi in 2006 - 2008. The accessions were grown in loamy soil in a single row of 4 meters length with inter row spacing of $75 \mathrm{~cm}$. All recommended agricultural practices were followed for this crop production. The experiment was set up in a Randomized Complete Block (RCB) design with three replications. In each experimental plot twenty cocoyam accessions propagules were planted with plant to plant spacing of $0.75 \mathrm{~m}$ and row to row spacing

*Corresponding author: E-mail: krshnnd@yahoo.com 
of $1 \mathrm{~m}$. When plant growth is very stunted, leaves become yellowish, dry and dropping then the quantitative parameters were observed and data were collected following descriptors of cocoyam with necessary modifications (Anomymous, 1989). Data were recorded for plant height (PLH), Petiole length (PEL), petiole breadth (PEB) leaf length (LEL), leaf breadth (LEB), leaf number (LEN), leaf area Index (LAI), which was calculated by leaf length $\mathrm{x}$ leaf breadth $\mathrm{x}$ 0.75 (Montgomery, 1911), corm length (CRL), corm breadth (CRB), cormel length (COL), cormel breadth (COB), cormel number (CON), cormel weight (COW), corm weight (CRW), sucker number (SUN), total fresh weight (TFW) and yield per plant (YPP).

The collected data were analyzed following the biometrical techniques of analysis developed by Mather (Mather, 1949) based on a mathematical model (Fisher et al.,1932) using the SPSS and MS Excel Software. Mean and critical differences were worked out by the method of analysis of variance used for randomized block design. After collection of data, analysis was done separately for each character. The analysis of variance for each character under the study was performed by F Test (Cochran and Cox, 1960, Singh and Chaudhary, 1977). Phenotypic and genotypic correlation coefficient for all possible combinations was computed from the components of variance and covariance following AL-Jibouri and co-workers (AL-Jibouri et al., 1958). The path coefficient analysis was done by using Wright's (Wright's 1921, 1923) formula was extended by Dewey and Lu (1959).

\section{Results and discussion}

At genotypic level highly significant and positive correlation was found with sucker number and yield per plant. Positive and highly significant correlation was found with cormel weight, cormel length, cormel breadth and yield per plant (Table-1).

At Phenotypic level highly significant and positive correlation was found with corm weight, sucker number and yield per plant. Highly significant and positive correlation was also found with cormel weight, cormel number, cormel length, cormel breadth, sucker number, and yield per plant. Significant and positive correlation was found sucker number with yield per plant.

Seventy one association showed slightly higher in magnitude at genotypically than their corresponding phenotypic correlation coefficients, indicating a fairly association between the characters studied (Table 1.). On the other hand in general sixty five associations showed phenotypically higher in magnitude than their genotypic correlation indicated that perhaps environmental factors played a major role in the expression of association. Corm weight showed significant and positive correlation with cormel weight, cormel number, cormel length, cormel breadth, sucker number, total fresh weight and yield per plant both genotypic and phenotypic level. Sucker number also showed positive and significant correlation with yield per plant in both level. Phenotypically corm length showed significant and positive relation with corm weight, sucker number and yield per plant. In the genotypic level only seven associations showed significant and positive correlation. Mohon and Co-workers (Mohon Kumer et al., 1990) reported positive and significant correlation between cormel yield and cormel weight in taro. Pandey and Co-workers (Pandey et al., 1996) studied 31 genotypes of taro with 8 yield contributed characters and observed that yield per plant was significantly and positively correlated with most of character at both phenotypic and genotypic levels. Dwivedi and Sen Co-workers (Dwivedi and Sen, 1999) studied thirty genotypes of taro for correlation and observed that cormel yield had positive and significant association with the length and girth of main sucker, number of cormels per plant an corm weight but it was negatively correlated with corm /cormel ratio. (Velayudhan, et al., 2000) found that the characters cormel number, cormel thickness, plant height, leaf length and leaf width had higher positive correlation with cormel yield where as leaf number was negatively correlated with yield. Cheema and Co-workers (Cheema et al., 2007) studied in arvi total yield per plant was positively and significantly correlated with number of corms and cormels per plant and corm length.

The path coefficient analysis which measures the direct as well as indirect effect of one variable through another on the end product and it was worked out both at genotypic and phenotypic levels and the results are shown in Table 2 and Table 3 respectively.

At genotypic level plant height showed high positive indirect effect on yield per plant through corm length. Genotypic association of petiole length with yield per plant was moderate and positive. Leaf area index showed positive and indirect effect via leaf number, corm length, corm weight and sucker number. Strong positive association of corm length was found with yield per plant. Corm weight showed direct and positive effect on yield per plant. Positive and indirect effects showed through cormel number, cormel breadth and sucker number. Corm weight showed direct and positive effect on yield per plant. Positive and indirect effects showed through cormel number, cormel breadth and sucker number. Cormel length had positive direct effect on yield per plant. Positive and indirect effects were observed through leaf breadth, leaf area index, corm weight, cormel number, cormel breadth. Cormel breadth was showed high positive direct effect on yield per plant. Positive and indirect effects were also observed through petiole length, leaf length, leaf breadth, leaf area index, corm weight and cormel number. Sucker number per plant showed high positive direct effect on yield per plant. Positive and indirect effect for this trait on yield per plant was observed via corm length and cormel number. Total fresh weight showed positive and indirect effect through corm length and sucker number on yield per plant. 


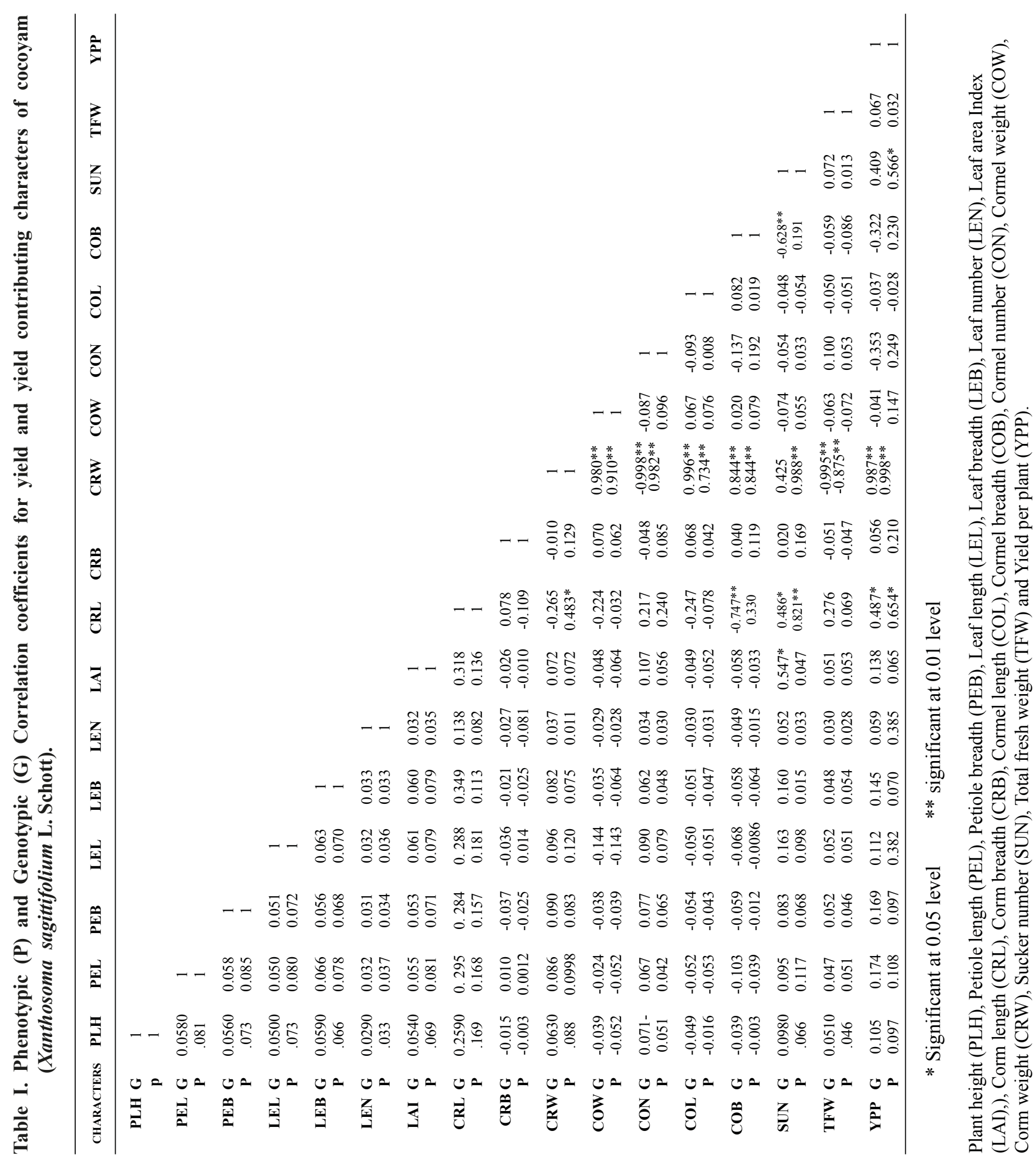

At phenotypic level direct and indirect positive effects through leaf length, leaf number, corm length, cormel number, sucker number were responsible for making the correlation insignificant leaf breadth and positive $\left(r_{p}=0.097\right)$. Direct effect of petiole length, petiole breadth, leaf length leaf breadth on yield per plant was positive. Positive indirect effects were observed via leaf number, corm length, cormel number and sucker number which subsequently reduce the negative effects of those characters. Direct effect of corm 


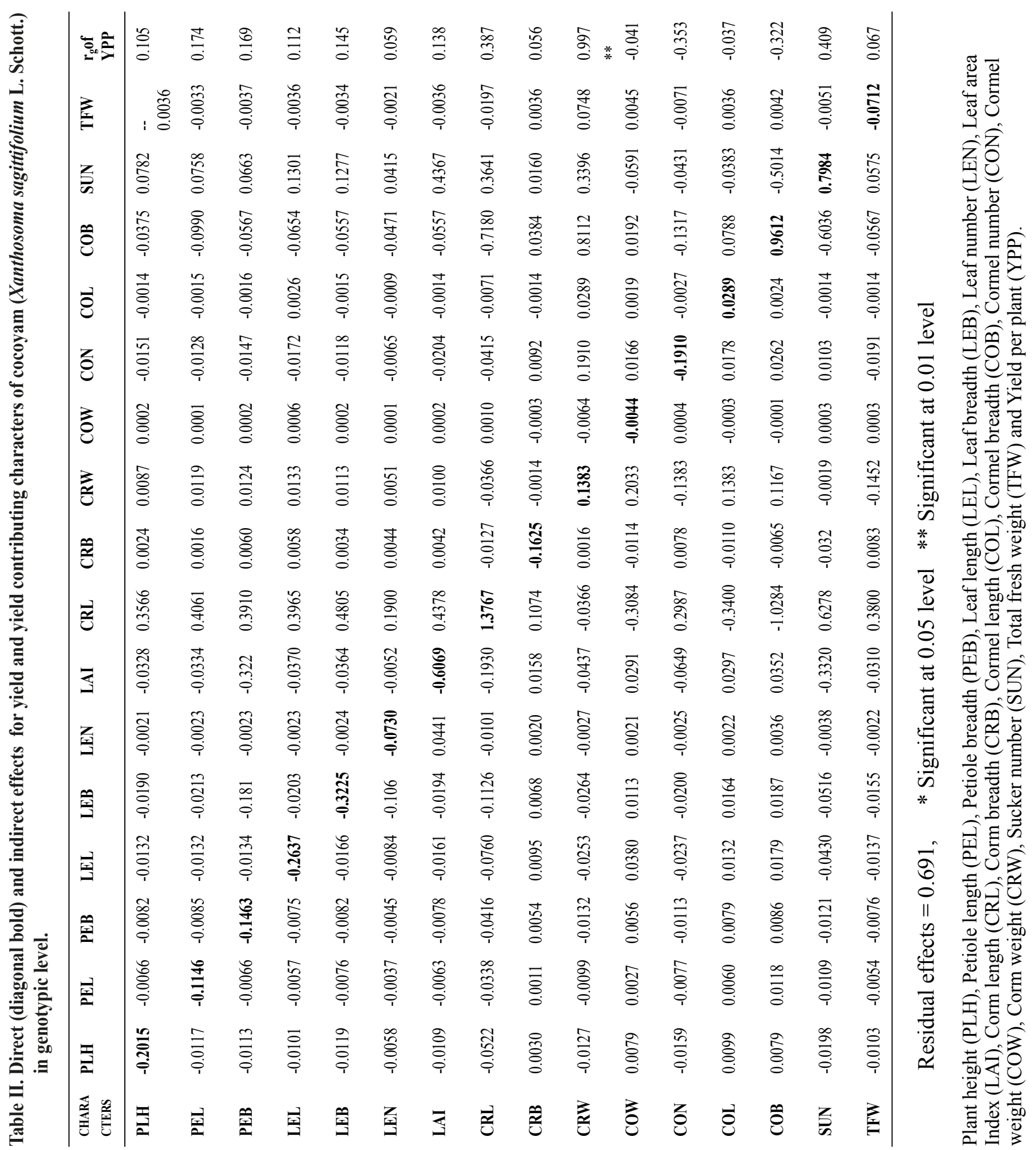

length on yield per plant was positive. Indirect and positive effects were found through leaf length, leaf number, cormel number, cormel breadth and sucker number. Corm weight showed indirect and positive effect the on yield per plant through leaf length, corm breadth cormel weight, cormel number, cormel length, cormel breadth, sucker number and total fresh weight. Cormel weight and cormel length had positive direct effect on yield per plant. Indirect and positive effect was observed through corm breadth, cormel 


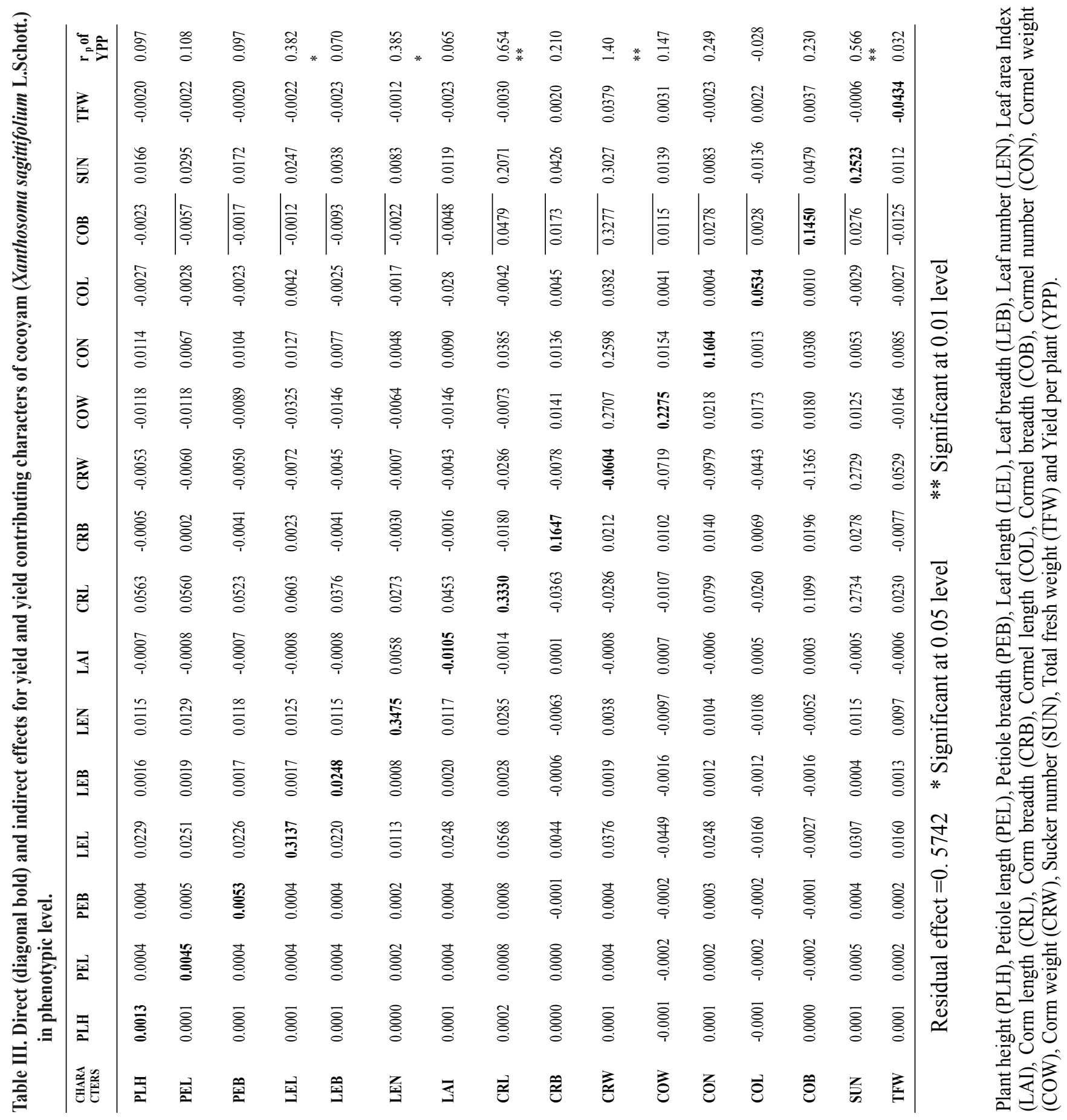

number, cormel breadth, sucker number. Sucker number per plant contributed positive direct effect on yield per plant. Positive and indirect effect was found through leaf number, corm length, corm breadth, corm weight, cormel weight, cormel breadth. Total fresh weight contributed positive and small amount of indirect effects on yield per plant through leaf length, corm length, corm weight and sucker number. Paul and Co-workers (Paul and Bari, 2011) evaluated thirty accessions of taro (Colocasia esculenta $\mathrm{L}$ ) varieties were to estimate the direct and indirect effects and found plant height, petiole length, corm breadth, cormel number, cormel length exhibited direct effect on yield per plant at the genotypic level. Cormel weight and cormel breadth had the highest direct effect on 
yield per plant at the phenotypic level. They also noticed residual effect was 0.3043 at the genotypic level and that at phenotypic level was 0.4874 .

\section{Conclusion}

The characters corm length, cormel breadth, sucker number, leaf number, leaf length can play the significant role for increasing yield per plant. These characters could be utilized by breeders as selection criteria to isolate higher yielding genotypes.

\section{Acknowledgement}

Expression of gratefulness to Institute of Biological Sciences, University of Rajshahi, Rahshahi-6205, Ministry of Science and Technology \& Communication, Government of Bangladesh and University Grant Commission (UGC), Agargaon, Dhaka-1207 for their partly financial help as fellowship to first author.

\section{References}

Al-Jibouri, H.A., Miller. R. A. and Robinson, H. F (1958).Genotypic and environmental variances and co variances in an upland cotton across of inter specific origin Agron. J. 50: 633-37.

Anomymous, CEI (Centro de Exportaciones Inversiones de Nicaragua)(2005).Servicio de Inteligencia commercial.Nicaragua: Exportaciones Diciember2004.

Cheema, D.S., Singh, H., Dhatt, A.S. and Gang, N. (2007). Studies on genetic variability and Correlation for yield and quality traits in Arvi (Colocasia esculenta Schott).International Society For Horticultural Science, Acta Horticulturae 752.

Cochran, W.G. and Cox, G.M. (1960), Experimental design. $2^{\text {nd }}$ edition. John Willey and Sons, Inc. New York

Coursey, D.G. (1983), Potential utilization of the major root and tuber crops, with emphasis on human,animal and industrial uses. In Tropical Root Crops.Production and uses in Africa, 25-35.(Eds E.R.Terry, E.V. Doku, O.B. Arene and N.M. Mahungu). Douala. Cameroon.

Dwivedi, A.K. and Sen, H. (1999). Correlation and path coefficient studies in taro (Colocasia esculenta var.antiquorum). J. root crops 25(1): 51 - 54 .

Fisher, R.A., Immer, R.R. and Tedin, O. (1932). The genetic interpretation of statistics on the third degree in the inheritance of quantitative inheritance. Genetics 17: 107 - 124.

Anomymous, IBPGRI (1989).Descriptors for cocoyam (Xanthosoma sagittifolium).IPGRI, Rome, Italy. pp 15-31
Mather, K. (1949). Biometrical genetics, Dover publication. Inc. New York.

Anomymous, MAG-FOR (2005). Informe de production agropecuaria de Nicaragua 2003-2004, Direction de Estadisticas del $M A G-F O R$, Nicaragua.

Montgomery, E.G. (1911).Correlation studies in corm.Neb. Agr. Exp. Sta. Ann. Rep. 24: 108-159.

Mohon Kumar C.R., Sarawathy, P and Sadanandan, N.(1990), Correlation and Path coefficient analysis on yield and yield component in Taro. J Root Crops 16(2): 140 -141.

Onwueme, I. C. and Charles, W. B. (1994). Section D: Edible aroids. In.Tropical root and tuber crops. Production, Perspectives and Future Prospects, P, FAO, Plant production and protection paper. 126: 139 -161.

Pandey, G. Dhobal, V.K. and Sapra, R.L. (1996). Genetic variability, correlation and path analysis in Taro.(Colocasia esculenta). J. Hill .Res. (India) 9(2): 299 - 302.

Paul, K .K. and Bari, M.A. (2011). Studies on Direct and Indirect Effects of Different Plant Characters on Yield of Taro (Colocasia esculenta L. Schott) var. antiquorum. The Agriculturists 9 (1\&2): 89-98.

Singh, R.K. and Chaudhary, B. D. (1977). Biometrical methods in quantitative genetic analysis .Kalnani publishers, New Delhi, India. pp 49 - 100.

Tambong, J. T., Ndzana, X., Wutoh, J.G and Dadson, R. (1997). Variability and germplasm loss in Cameroon national collection of Cocoyam (Xanthosoma sagittifolium Schott. (L.)). Plant genetic resources News letters 112: 49 - 54.

Tambong,J. T, Poppe, J. and Hofte, M.(1999). Pathogenocity, electrophoretic characterization and in planta detection of the cocoyam root rot disease pathogen, Pythium myriothylum. European Journal of plant pathology 105: 597 - 607.

Wilson, J.E. (1984). Cocoyam. In: The Physiology of tropical field crops. New York, London: John Wiley and Sons Ltd. pp $589-605$.

Wright, S.(1921). Correlation and causation. J. Agric. Res. 20: $557-585$.

Wright, S.(1923).The theory of path coefficient a reply to Niles criticism. Genetics 8: 239- 255.

Received: 28 March 2013; Revised: 28 January 2015;

Accepted: 24 March 2015. 